\title{
MODEL SEIR UNTUK PENYEBARAN PENYAKIT HEPATITIS C DENGAN PENGOBATAN PADA POPULASI TERINFEKSI KRONIS
}

\author{
FADILAH ILAHI $^{*}$, NUR FADILATURROHMAH $^{2}$ \\ 1,2Jurusan Matematika, Fakultas Sains dan Teknologi, UIN Sunan Gunung Djati, Bandung \\ *fadilah.ilahi@uinsgd.ac.id
}

\begin{abstract}
ABSTRAK
Penyakit hepatitis $\mathrm{C}$ merupakan salah satu penyakit yang menjadi masalah kesehatan dunia. Penyakit ini disebabkan oleh virus hepatitis tipe C. Kebanyakan individu baru menyadari terinfeksi ketika hepatitis C semakin kronis. Selain itu, jika individu yang terinfeksi tidak mendapat pengobatan secara medis dapat menyebabkan kerusakan hati bahkan sampai kematian. Maka dari itu, model matematika diusulkan sebagai salah satu alternatif dalam meningkatkan pemahaman mengenai penularan dan pencegahan dalam penyebaran virus hepatitis $\mathrm{C}$ dengan adanya pengobatan pada populasi terinfeksi kronis. Model yang digunakan merupakan tipe SEIR dengan menggunakan 5 kompartemen yaitu rentan terinfeksi, terjangkit infeksi, terinfeksi akut, terinfeksi kronis, dan sembuh dari infeksi. Model ini memiliki dua titik kesetimbangan yaitu titik kesetimbangan bebas penyakit yang merepresentasikan keadaan ketika virus tidak mewabah serta titik endemik yang merepresentasikan bahwa virus mewabah karena adanya interaksi antar individu. Analisis sensitivitas sangat diperlukan untuk mengetahui hal-hal yang berpengaruh dalam mencegah penyebaran dan pengobatan hepatitis C. Berdasarkan hasil analisis dan simulasi diperoleh jika semakin banyak penderita hepatitis $\mathrm{C}$ kronis yang mendapat pengobatan secara medis maka dapat membantu menekan penyebaran virus.
\end{abstract}

Kata Kunci: Hepatitis C, penyebaran virus, populasi kronis, model SEIR.

\begin{abstract}
Hepatitis $C$ is one of world health problems. This disease is caused by the hepatitis $C$ virus and most individuals are aware of infection when it becomes chronic. In addition, if an infected individual does not receive medical treatment, it may lead to liver damage and even death. Therefore, a mathematical model is proposed as an alternative in understanding of transmission and offered prevention in the spread of the hepatitis $C$ virus in the presence of treatment in chronically infected population. The model used is a type of SEIR model using five compartments: Susceptible (S), Infection (I), Acute infection (A), Chronic infection $(C)$, and Recovered $(R)$. This model has two equilibrium points, namely a disease-free equilibrium point which represents a virgin population and an endemic point which represents an outbreak in population. Sensitivity analysis is needed to determine parameters to prevent the spread of disease and treatment of hepatitis $C$. Based on the results of the analysis and simulation, it is obtained that chronic hepatitis $C$ sufferers are the priority who receive medical treatment due to reduce the spread of the virus.
\end{abstract}

Keywords: Hepatitis C, virus spread, chronic population, SEIR model.

\section{Pendahuluan}


Hepatitis merupakan penyakit yang menyebabkan terjadinya peradangan pada hati yang disebabkan oleh virus. Berdasarkan pada sifat patogenesis dan karakteristik dari virus dapat dibedakan menjadi 5 jenis hepatitis antara lain hepatitis A, hepatitis B, hepatitis C, hepatitis D, dan hepatitis E. Virus hepatitis adalah tantangan kesehatan masyarakat internasional yang sama dengan penyakit menular utama lainnya seperti HIV, TBC dan malaria [1]-[3].

Virus hepatitis $\mathrm{C}(\mathrm{HCV})$ adalah penyebab utama penyakit hati kronis, sirosis, dan karsinoma hepatoseluler, serta indikasi paling umum untuk transplantasi hati di banyak Negara [4]. Dilaporkan bahwa lebih dari 170 juta orang telah terkena dampak serius di seluruh dunia [5]. Hal ini menyebabkan HCV menjadi salah satu jenis penyakit hepatitis yang memerlukan perhatian khusus untuk ditangani. Faktor yang paling sering dikutip untuk sebagian besar penularan HCV di seluruh dunia adalah penggunaan narkoba suntik, transfusi darah yang tidak disaring, suntikan terapeutik yang tidak aman, dan prosedur kesehatan lainnya [6].

Seseorang akan terkena virus hepatitis $\mathrm{C}$ jika melakukan kontak dengan individu yang telah terinfeksi. Hal ini menyebabkan orang tersebut terjangkit virus hepatitis $\mathrm{C}$ dan virus mengalami masa inkubasi dalam tubuhnya sekitar 2 minggu sampai 6 bulan. Setelah masa inkubasi virus selesai, maka virus telah menyebar dalam aliran darah dan menyebabkan peradangan pada hati. Keadaan ini menyebabkan orang tersebut terinfeksi hepatitis $\mathrm{C}$ secara akut. Selanjutnya, jika virus sudah berada dalam tubuh dalam jangka waktu yang lama maka orang yang semula terinfeksi secara akut akan berubah menjadi terinfeksi secara kronis. Dari kasus-kasus kronis ini, sekitar 10-20\% berkembang menjadi sirosis hati, sekitar 5\% mengembangkan karsinoma hepatoseluler (HCC) [7]-[11]. Pengobatan antivirus, terutama pada tahap awal terjadinya HCV adalah strategi yang sangat efektif [7].

Beberapa penelitian mengenai transmisi dan perawatan untuk penyakit Hepatitis $\mathrm{C}$ telah banyak dibahas oleh penulis diantaranya oleh Tao Feng et al. yang mengkonstruksi model dengan pendekatan stokastik, bukan deterministik [12]. Sedangkan pada artikel lain memaparkan bahwa pengobatan terhadap pasien Hepatitis $C$ dapat berupa perawatan medis seperti pemberian obat dan vaksin maupun perawatan yang bersifat non-medis (immune system) [2], [5], [7]-[12]. Pada artikel ini, penulis mengkonstruksi model deterministik sederhana yang menjelaskan proses transmisi virus Hepatitis $\mathrm{C}$ dengan mempertimbangkan dua subpopulasi pada fase penyebarannya, yaitu pada fase akut dan fase kronis. Selanjutnya, penulis akan menjelaskan proses transmisi virus Hepatitis C melalui model SEIR dengan pengobatan pada populasi terinfeksi kronis sebagai salah satu alternatif dalam meningkatkan pemahaman mengenai penyebaran dan pencegahan virus hepatitis $C$.

\section{Metode Penelitian}

Penelitian mengenai model transmisi hepatitis $C$ ini terbagi menjadi beberapa bagian, yaitu penetapan asumsi dan diagram interaksi, konstruksi model matematika, analisis titik tetap dan kestabilannya, analisis sensitivitas, hingga membuat simulasi dinamik. Asumsi pada model ini bertujuan untuk membatasi masalah dan membuat model yang lebih sederhana daripada kondisi riil di lapangan namun tetap memperhatikan beberapa parameter dan varibel penting dalam proses transmisi. Sedangkan diagram interaksi diperlukan untuk menggambarkan proses transmisi. Analisis titik tetap dan kestabilannya akan dilakukan dengan menggunakan matriks Jacobi dan nilai eigen yang diperoleh dari matriks tersebut. Untuk melihat hubungan antar varibel terhadap angka reproduksi dasar dilakukan analisis sensitivitas. Simulasi dinamik bertujuan untuk melihat tren dari proses transmisi penyakit dan menentukan suatu prediksi di masa yang akan datang sehingga dapat mengambil langkah pencegahan yang tepat.

Dalam mengkonstruksi model SEIR untuk transmisi virus hepatitis $\mathrm{C}$ dengan adanya pengobatan pada populasi terinfeksi kronis diperlukan beberapa asumsi. Asumsi-asumsi tersebut antara lain: 
1. Populasi terdiri dari 5 subpopulasi antara lain rentan terinfeksi $(S)$, terjangkit infeksi $(E)$, terinfeksi akut $(P)$, terinfeksi kronis $(C)$, dan sembuh $(R)$.

2. Semua parameter bernilai positif. Hal ini dikarenakan sebuah populasi tidak mungkin bernilai negatif.

3. Populasi bersifat tertutup dan konstan artinya bertambahnya semua populasi terjadi karena adanya rekrutmen dan berkurangnya populasi kareana adanya kematian. Rekrutmen populasi diperoleh karena adanya kelahiran.

4. Individu yang bersifat rentan terkena infeksi virus hepatitis $C$ akan berada pada populasi $S$.

5. Suatu individu dinyatakan terjangkit infeksi $(E)$ jika adanya kontak antara individu yang rentan terinfeksi dengan individu yang terinfeksi virus hepatitis $C$.

6. Individu yang telah terjangkit infeksi akan bertransisi menjadi individu yang terinfeksi akut $(P)$.

7. Individu yang telah terinfeksi akut $(P)$ dan tidak sembuh dengan bantuan inang primer akan bertransisi menjadi individu yang terinfeksi kronis $(C)$.

8. Individu yang sembuh secara permanen akibat bantuan inang primer pada populasi terinfeksi akut $(P)$ dan terinfeksi kronis $(C)$ serta sembuh dengan bantuan medis pada populasi terinfeksi kronis $(C)$ akan bertransisi menjadi individu pada populasi sembuh $(R)$

9. Adanya kematian yang diakibatkan oleh penyakit yang terjadi pada populasi $C$.

Berdasarkan beberapa asumsi diatas, dapat dideskripsikan hal-hal yang mempengaruhi penyebaran virus hepatitis $\mathrm{C}$ di setiap sub-populasi. Pada subpopulasi rentan (S) terdapat rekrutmen sebesar $\Lambda$ yang menambah jumlah individu di subpopulasi tersebut. Subpopulasi $\mathrm{S}$ dapat berinteraksi dengan individu di subpopulasi $\mathrm{P}$ dan $\mathrm{C}$ dengan laju penyebaran penyakit di kompartemen tersebut berturut-turut dinotasikan dengan $\beta$ dan $\beta z$ sehingga keduanya akan menambah subpopulasi terpapar E. Individu terpapar dapat bertransisi menjadi akut dengan laju sebesar $\rho$. Selanjutnya individu akut dapat berpindah menjadi kronis dengan laju sebesar $\varepsilon$ atau sembuh dengan laju $\sigma$. Pada fase kronis, seseorang dapat sembuh dengan laju $f$ atau meninggal dengan laju $d$. Sedangkan kematian alami terdapat di setiap kompartemen dengan laju yang sama yaitu sebesar $\mu$. Berikut diagram interaksi untuk transmisi virus hepatitis $\mathrm{C}$ :

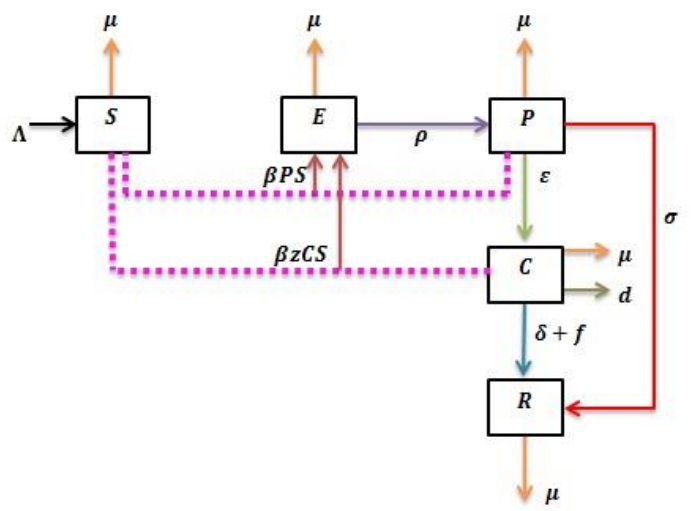

Gambar 1. Diagram interaksi transmisi virus Hepatitis C

Berdasarkan diagram interaksi di atas, maka dapat dikonstruksi menjadi model SEIR dengan persamaan diferensial biasa yang bergantung terhadap waktu untuk transmisi virus hepatitis $\mathrm{C}$ dengan pengobatan pada populasi terinfeksi kronis. Sistem persaman tersebut adalah:

$$
\begin{aligned}
& \frac{d S}{d t}=\Lambda-\beta(P+z C) S-\mu S \\
& \frac{d E}{d t}=\beta(P+z C) S-\mu E-\rho E
\end{aligned}
$$




$$
\begin{aligned}
& \frac{d P}{d t}=\rho E-(\mu+\sigma+\varepsilon) P \\
& \frac{d C}{d t}=\varepsilon \mathrm{P}-(\mu+f+\delta+d) C \\
& \frac{d R}{d t}=\sigma P+f C+\delta C-\mu R
\end{aligned}
$$

dengan

$$
N=S+E+P+C+R
$$

Sistem persamaan tersebut dapat ditulis dalam bentuk $\hat{G}=f(x)$ untuk setiap $G \in \Omega$ dengan

$$
\Omega=\left\{(S, E, P, C, R) \in R^{5+} \mid N \leq \frac{4}{\mu}\right\}
$$

\section{Hasil dan Pembahasan}

Berdasarkan system (1) diperoleh dua titik kesetimbagan untuk model SEIR untuk transmisi virus hepatitis $\mathrm{C}$ yaitu titik kesetimbangan bebas penyakit dan titik kesetimbangan endemic. Titik kesetimbangan menjelaskan kondisi yang tidak akan berubah untuk jangka waktu yang panjang, artinya pada titik bebas penyakit populasi tersebut akan tetap mempertahankan kondisi populasi virgin (tidak ada penyakit). Sedangkan pada titik endemik, suatu populasi akan mempertahankan adanya penularan namun dalam jumlah yang konstan. Secara matematis, kedua titik ekuilibrium tersebut dinotasikan sebagai berikut:

1. Titik Kesetimbangan Bebas Penyakit

$$
\begin{aligned}
E q_{1} & =\left(S_{1}, E_{1}, P_{1}, C_{1}, R_{1}\right) \\
& =\left(\frac{\Lambda}{\mu}, 0,0,0,0\right)
\end{aligned}
$$

2. Titik Kesetimbangan Endemik

$$
\begin{aligned}
E q^{*}=\left(S^{*}, E^{*}, P^{*}, C^{*}, R^{*}\right) & \\
& =\left(\frac{g h j}{\rho \beta k}, \frac{\Lambda \rho \beta k-\mu g h j}{\rho \beta k j}, \frac{\rho}{g} E^{*}, \frac{\rho \varepsilon}{g h} E^{*},\left(\frac{\sigma h+\varepsilon l}{\mu g h}\right) \rho E^{*}\right)
\end{aligned}
$$

dimana

$$
\begin{aligned}
& g=(\mu+\sigma+\varepsilon) \\
& h=(\mu+f+\delta+d) \\
& j=(\mu+\rho) \\
& k=(\mu+f+\delta+d+\varepsilon z) \\
& l=(f+\delta)
\end{aligned}
$$

\section{Angka Reproduksi Dasar $\left(R_{0}\right)$}

Selanjutnya akan dicari angka reproduksi dasar yang mendeskripsikan infeksi sekunder yang dihasilkan dari satu individu yang terinfeksi. Misalkan untuk Hepatitis C, basic reproduction number berdasarkan penelitian terdahulu berada di angka 0,59-1,08 [1]. Dengan demikian, jika terdapat satu orang terinfeksi Hepatitis C, maka orang tersebut berpotensi untuk menularkan ke satu orang berikutnya. Dengan menggunakan Next Generation Matrix (NGM) diperoleh angka reproduksi dasar $\left(R_{0}\right)$ dari system $(1)$ yaitu

$$
R_{0}=\frac{\beta \Lambda \rho}{\mu(\mu+\rho)(\mu+\sigma+\varepsilon)}\left(1+\frac{z \varepsilon}{(\mu+f+\delta+d)}\right)
$$

Dengan diperolehnya $R_{0}$ maka titik kesetimbangan endemik dapat ditulis sebagai 
$E q^{*}=\left(S^{*}, E^{*}, P^{*}, C^{*}, R^{*}\right)$

$=\left(\frac{g h j}{\rho \beta k}, \frac{g h \mu\left(R_{0}-1\right)}{\rho \beta k}, \frac{h \mu\left(R_{0}-1\right)}{\beta k}, \frac{\mu \varepsilon\left(R_{0}-1\right)}{\beta k}, \frac{m\left(R_{0}-1\right)}{\beta k}\right)$

dan memiliki syarat eksis $R_{0}>1$.

\section{Analisis Kestabilan}

Kestabilan titik tetap diperoleh dengan linearisasi system (4) melalui matriks Jacobi. Analisis Kestabilan untuk kedua titik kesetimbangan secara umum memenuhi persamaan berikut

$$
(-\mu-\lambda)\left(a_{0} \lambda^{4}+a_{1} \lambda^{3}+a_{2} \lambda^{2}+a_{3} \lambda+a_{4}\right)=0
$$

dengan nilai eigen $\lambda_{1}=-\mu$ dan nilai eigen lainnya memenuhi syarat perlu dan kondisi cukup untuk polinomial kuartet dalam kriteria Routh-Hurwitz. Untuk titik kesetimbangan bebas penyakit, polinomial kuartet dalam kriteria Routh-Hurwitz ketika $R_{0}<1$, sedangkan untuk titik kesetimbangan endemik haruslah saat $R_{0}>1$. Dalam hal ini, agar populasi tersebut bebas penyakit, maka angka reproduksi dasar haruslah bernilai kurang dari satu (tidak ada lagi infeksi yang bisa ditularkan kepada orang berikutnya), sedangkan jika lebih dari satu maka populasi tersebut akan menjadi populasi yang endemic.

\section{Analisis Sensitivitas}

Pada bagian ini akan dilakukan analisis sensitivitas dari parameter $\beta, \Lambda, \rho, \mu, f, \delta, d, z, \varepsilon$, dan $\sigma$ terhadap angka reproduksi dasar $\left(R_{0}\right)$. Dengan dilakukannya analisis ini diharapkan dapat menentukan parameter mana yang dapat menekan penyebaran penyakit dan yang dapat meningkatkan transmisinya. Dalam melakukan analisis sensitivitas pada model SEIR untuk transmisi virus hepatitis $C$ dengan pengobatan pada populasi terinfeksi kronis digunakan nilai awal antara lain:

$\beta=0.05, \Lambda=15, \rho=0.4, \mu=0.09, f=0.09, \delta=0.2, d=0.01, z=0.034, \varepsilon=0.3, \sigma=0.03$.

Berikut ini merupakan salah satu langkah analisis sensitivitas untuk parameter $\beta$ sedangkan pada tabel 2 merupakan hasil indeks sensitivitas untuk setiap parameter

$$
\mathrm{Y}_{\beta}^{R_{0}}=\frac{\partial R_{0}}{\partial \beta} \times \frac{\beta}{R_{0}}
$$

Tabel 2. Nilai indeks sensitivitas

\begin{tabular}{|c|c|}
\hline Parameter & Indeks Sensitivitas \\
\hline$\beta$ & 1 \\
\hline$\Lambda$ & 1 \\
\hline$\rho$ & 0.1836734700 \\
\hline$\mu$ & -1.403840858 \\
\hline$f$ & -0.005881674767 \\
\hline$\delta$ & -0.01307038837 \\
\hline$d$ & -0.0006535194186 \\
\hline$z$ & 0.02548725637 \\
\hline$\varepsilon$ & -0.6887984581 \\
\hline$\sigma$ & -0.07142857143 \\
\hline
\end{tabular}

Dari table 2 di atas, dapat diketahui bahwa parameter $\beta, \Lambda, \rho, z$ mempunyai hubungan positif dengan $R_{0}$ sedangkan parameter $\mu, f, \delta, d, \varepsilon, \sigma$ mempunyai hubungan negative dengan $R_{0}$. 


\section{Simulasi Dinamik}

Simulasi dinamik yang ditampilkan pada bagian ini merupakan hasil analisis yang dituangkan dalam bentruk grafik. Data yang diambil merupakan data sebarang namun telah disesuaikan dan memenuhi syarat eksis dan syarat stabil baik pada kondisi bebas penyakit maupun kondisi endemik. Pada simulasi dinamik ini, diberikan tiga nilai awal untuk setiap kompartemen.

Tabel 3. Nilai awal untuk simulasi dinamik

\begin{tabular}{|c|c|c|}
\hline Nilai awal 1 & Nilai awal 2 & Nilai awal 3 \\
\hline$S(0)=23$ & $S(0)=30$ & $S(0)=15$ \\
\hline$E(0)=19$ & $E(0)=20$ & $E(0)=10$ \\
\hline$P(0)=13$ & $P(0)=15$ & $P(0)=7$ \\
\hline$C(0)=9$ & $C(0)=10$ & $C(0)=4$ \\
\hline$R(0)=13$ & $R(0)=13$ & $R(0)=5$ \\
\hline
\end{tabular}

Sedangkan nilai parameter yang digunakan untuk simulasi adalah sebagai berikut:

Tabel 4. Nilai parameter untuk simulasi dinamik

\begin{tabular}{|c|c|}
\hline Simulasi 1 & Simulasi 2 \\
\hline$\beta=0.09$ & $\beta=0.05$ \\
\hline$\Lambda=6$ & $\Lambda=15$ \\
\hline$\rho=0.04$ & $\rho=0.4$ \\
\hline$\mu=0.09$ & $\mu=0.09$ \\
\hline$f=0.009$ & $f=0.09$ \\
\hline$\delta=0.2$ & $\delta=0.2$ \\
\hline$d=0.1$ & $d=0.01$ \\
\hline$z=0.034$ & $z=0.034$ \\
\hline$\varepsilon=0.3$ & $\varepsilon=0.3$ \\
\hline$\sigma=0.03$ & $\sigma=0.03$ \\
\hline
\end{tabular}

Berikut akan ditampilkan gambar hasil simulasi dinamik dengan menggunakan nilai awal dan nilai parameter tersebut

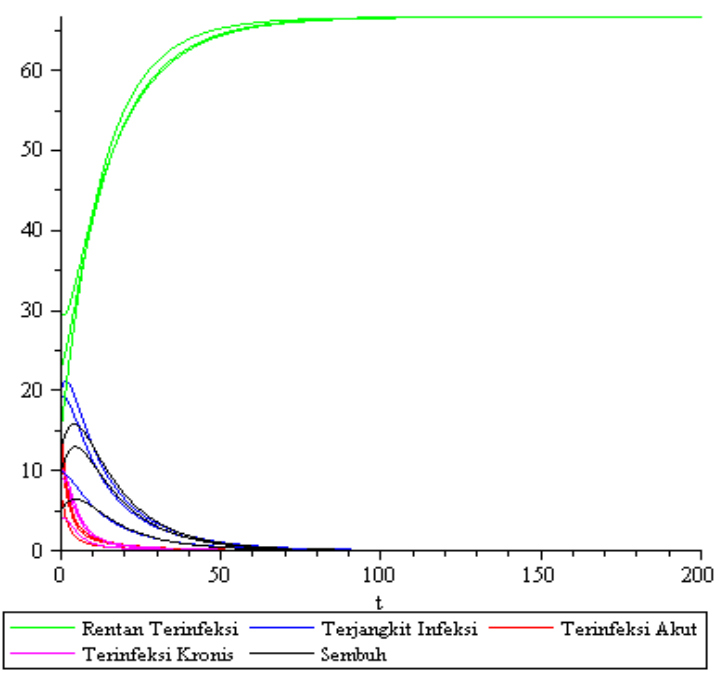

Gambar 2. Grafik simulasi dinamik dengan nilai parameter 1. 


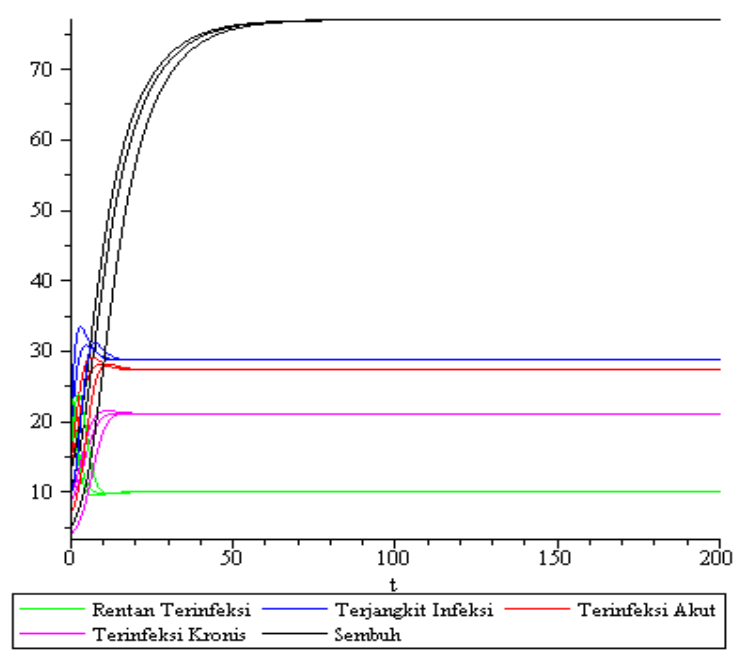

Gambar 3. Grafik simulasi dinamik dengan nilai parameter 2.

Gambar 2 merupakan grafik simulasi dengan nilai pada parameter pertama. Terlihat bahwa tidak ada interaksi antara individu pada populasi $S$ dengan individu pada populasi $E, P, C$, maupun $R$ sebab laju kontak dalam penyebaran virus memiliki peluang yang sangat kecil yaitu 0.009 . Selain itu, populasi $E, P, C$ dan $R$ seiring berjalannya bergerak menuju 0 akan tetapi populasi $R$ sempat mengalami peningkatan jumlah individu ketika $t<5$ hal ini disebabkan karena adanya perpindahan individu dari populasi $P$ dan $C$ karena adanya kesembuhan akibat inang primer maupun pengobatan secara medis. Sedangkan, pada populasi $S$ mengalami peningkatan dan stabil saat $t \geq 66$ serta nilai $R_{0}=0.1312651543<1$. Hal ini merepresentasikan bahwa setiap populasi pada simulasi dengan nilai parameter pertama bergerak menuju titik kesetimbangan bebas penyakit.

Gambar 3 merupakan grafik simulasi dengan nilai pada parameter kedua. Terlihat bahwa ada interaksi antara populasi $S$ dengan $P$ maupun $C$ menyebabkan adanya individu baru yang terjangkit infeksi HCV. Berdasarkan grafik di atas dapat diketahui bahwa jumlah individu yang terjangkit infeksi lebih banyak dibandingkan dengan jumlah individu pada populasi $P, C$ maupun $S$. Akan tetapi, jumlah individu pada populasi $R$ sangat mengalami kenaikan yang signifikan ketika $t$ berapa pada interval $t<53$ dan memiliki jumlah individu yang paling banyak dibandingkan semua populasi. Akan tetapi, ketika $t$ berada pada interval $53 \leq t<69$ terjadi penambahan individu tidak begitu signifikan dan ketika $t \geq 69$ jumlah individu dalam populasi mulai stabil. Nilai $R_{0}$ pada simulasi ini adalah 16.62056764. Hal ini merepresentasikan terjadinya penyebaran virus dan seiring berjalannya waktu semua populasi menuju titik kesetimbangan endemik.

\section{Simulasi Sensitivitas}

Pada simulasi analisis sensitivitas, akan dilihat bagaimana pengaruh setiap parameter terhadap perubahan nilai $R_{0}$. Berikut ini, gambar hasil simulasi dengan parameter yang paling berpengaruh terhadap penurunan dan kenaikan nilai $R_{0}$. 


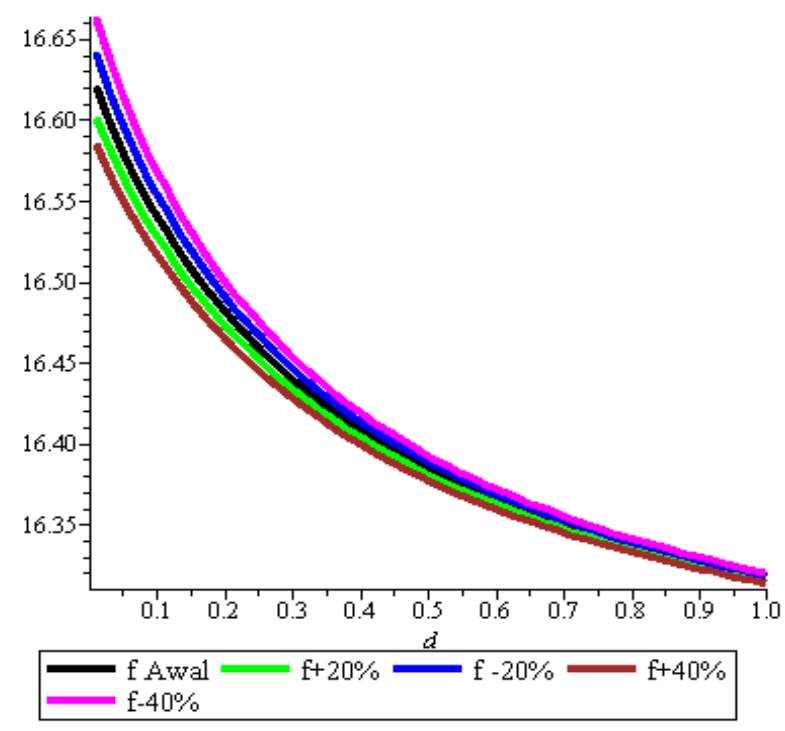

Gambar 4. Pengaruh $d$ dan $f$ terhadap $R_{0}$

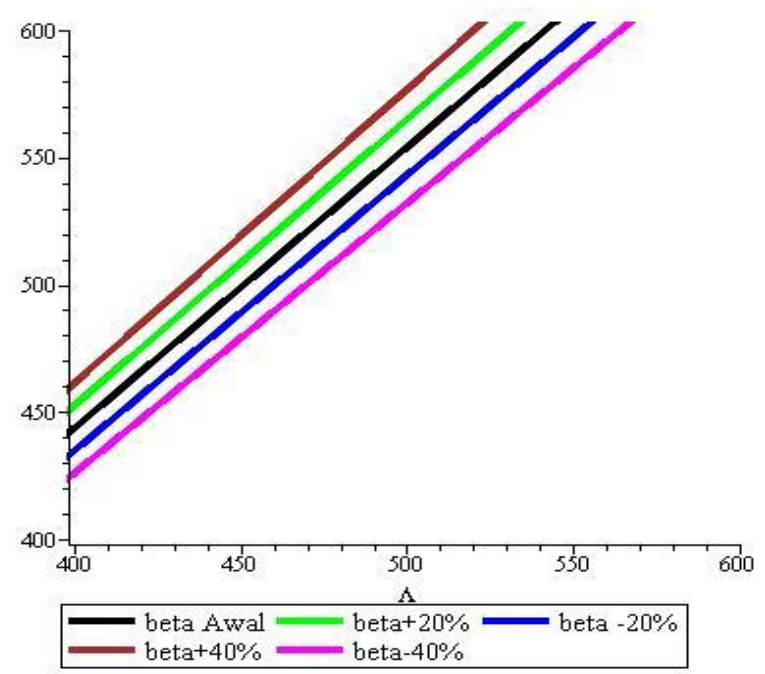

Gambar 5. Pengaruh $A$ dan $\beta$ terhadap $R_{0}$

Berdasarkan gambar 4, jika membuat garis secara vertikal yang memotong semua garis indeks sensitivitas $f$ dapat diketahui garis indeks sensitivitas yang pertama terpotong adalah garis $f$ dengan nilai yang lebih besar dibandingkan nilai $f$ yang lainnya. Adanya perubahan nilai $d$ dan $f$ yang semakin besar menyebabkan nilai $R_{0}$ semakin kecil. Artinya semakin besar laju kematian individu terinfeksi kronis dan laju penyembuhan dengan pemberian obat pada individu terinfeksi maka semakin kecil nilai $R_{0}$.

Pada gambar 5, apabila nilai $\Lambda$ dan $\beta$ naik maka hal ini akan mengakibatkan nilai $R_{0}$ semakin besar. Begitu pun sebaliknya, jika nilai $\Lambda$ dan $\beta$ turun maka hal ini akan mengakibatkan nilai $R_{0}$ mengalami penurunan. Hal ini berarti semakin besar laju rekrutmen dan laju kontak penyebaran virus maka semakin besar juga $R_{0}$ yang mengakibatkan terjadinya penyebaran virus yang lebih cepat.

\section{$4 \quad$ Kesimpulan dan Saran}


Berdasarkan hasil analisis dan simulasi di atas, proses transmisi virus hepatitis $\mathrm{C}$ dapat dilakukan treatment (perawatan) yang bersifat medis seperti obat pada fase kronis, namun obat tersebut belum secara signifikan menyembuhkan mengingat fase kronis adalah fase terakhir dalam proses perawatan pasien Hepatitis C. Bagaimanapun, jika laju penyebaran virus tinggi maka kemungkinan besar seseorang yang telah terjangkit virus Hepatitis $\mathrm{C}$ dapat menjadi semakin parah, misalkan dari awalnya terpapar menjadi akut, lalu berubah menjadi kronis. Akan tetapi, hal ini dapat ditangani dengan memberikan pengobatan secara medis terhadap populasi terinfeksi sehingga dapat menekan penyebaran virus. Sedangkan, untuk hasil simulasi analisis sensitivitas dapat diketahui bahwa untuk setiap parameter yang memiliki nilai positif dalam analisis sensitivitas akan mempengaruhi peningkatan jumlah individu yang terinfeksi. Sedangkan untuk setiap parameter yang bernilai negatif dalam analisis sensitivitas akan berguna untuk menekan penyebaran virus.

Saran yang ingin penulis sampaikan adalah dengan membangun model transmisi virus Hepatitis $\mathrm{C}$ dengan adanya pengobatan pada fase awal terjangkit, misalnya pada fase exposed atau fase akut, sehingga diharapkan penyebaran virus tersebut dapat ditekan secara signifikan dan memperoleh kondisi stabil bebas penyakit yang lebih cepat daripada model di atas.

\section{Daftar Pustaka}

[1] R. Shi and Y. Cui, "Global analysis of a mathematical model for Hepatitis C virus transmissions," Virus Res., vol. 217, pp. 8-17, 2016, doi: 10.1016/j.virusres.2016.02.006.

[2] M. D. Miller-Dickson, V. A. Meszaros, S. Almagro-Moreno, and C. Brandon Ogbunugafor, "Hepatitis $\mathrm{C}$ virus modelled as an indirectly transmitted infection highlights the centrality of injection drug equipment in disease dynamics," J. R. Soc. Interface, vol. 16, no. 158, 2019, doi: 10.1098/rsif.2019.0334.

[3] M. Merdan, Z. Bekiryazici, T. Kesemen, and T. Khaniyev, "Deterministic stability and random behavior of a Hepatitis C model," PLoS One, vol. 12, no. 7, pp. 1-17, 2017, doi: 10.1371/journal.pone.0181571.

[4] I. Hepatitis, C. V. Modeling, P. Infection, and V. P. Mechanisms, "crossm Dynamics and Viral Protein Mechanisms," vol. 92, no. 11, pp. 1-21, 2018.

[5] M. Major et al., "Modeling of patient virus titers suggests that availability of a vaccine could reduce hepatitis C virus transmission among injecting drug users," Sci. Transl. Med., vol. 10, no. 449, pp. 1-12, 2018, doi: 10.1126/scitranslmed.aao4496.

[6] J. P. Ángel-López and N. Arzola de la Peña, "VII Latin American Congress on Biomedical Engineering CLAIB 2016, Bucaramanga, Santander, Colombia, October 26th -28th, 2016," IFMBE Proc., vol. 60, pp. 520-523, 2017, doi: 10.1007/978-981-104086-3.

[7] Q. Chen et al., "Changes in hepatitis $\mathrm{C}$ burden and treatment trends in Europe during the era of direct-acting antivirals: A modelling study," BMJ Open, vol. 9, no. 6, pp. 1-11, 2019, doi: 10.1136/bmjopen-2018-026726.

[8] S. Baral, R. Roy, and N. M. Dixit, "Modeling how reversal of immune exhaustion elicits cure of chronic hepatitis $\mathrm{C}$ after the end of treatment with direct-acting antiviral agents," Immunol. Cell Biol., vol. 96, no. 9, pp. 969-980, 2018, doi: 10.1111/imcb.12161.

[9] S. Popping et al., "Early treatment of acute hepatitis C infection is cost-effective in HIVinfected men-who-have-sex-with-men," PLoS One, vol. 14, no. 1, pp. 1-15, 2019, doi: 10.1371/journal.pone.0210179. 
[10] R. Aggarwal et al., "Cost-effectiveness of hepatitis C treatment using generic directacting antivirals available in India," PLoS One, vol. 12, no. 5, pp. 1-15, 2017, doi: 10.1371/journal.pone.0176503.

[11] H. H. Ayoub and L. J. Abu-Raddad, "Impact of treatment on hepatitis C virus transmission and incidence in Egypt: A case for treatment as prevention," J. Viral Hepat., vol. 24, no. 6, pp. 486-495, 2017, doi: 10.1111/jvh.12671.

[12] T. Feng, Z. Qiu, and X. Meng, "Dynamics of a stochastic hepatitis C virus system with host immunity," Discret. Contin. Dyn. Syst. - Ser. B, vol. 24, no. 12, pp. 6367-6385, 2019, doi: 10.3934/dcdsb.2019143. 